\title{
Development of Learning Media Based on VideoScribe to Improve Writing Skill for Descriptive Text of English Language Study
}

\author{
Novita Aryuntini $^{1)}$, Indri Astuti ${ }^{2)}$, Yohanes Gatot Sutapa Yuliana ${ }^{3)}$ \\ ${ }^{1)}$ Universitas Tanjungpura, Pontianak, Indonesia \\ E-mail:aryoon30@gmail.com \\ ${ }^{2)}$ Universitas Tanjungpura, Pontianak, Indonesia \\ E-mail: indribk91@yahoo.com \\ ${ }^{3)}$ Universitas Tanjungpura, Pontianak, Indonesia \\ E-mail: gatot_fkip@yahoo.co.id
}

\begin{abstract}
This study generally aims to develop VideoScribe-based learning media to improve the ability in writing descriptive text in English subjects. The development model used in this study is a combination of Borg and Gall development research steps, and the design of 4D-Thiagarajan learning model includes initial research and information gathering, planning stages, design stages, development stages, revision, and final product stages. The techniques of data collection in this study were carried out through indirect communications and test. Data collection tools used was questionnaires, observation's sheet, and performance tests. The results showed that the design of instructional media development in this study consisted of (1) The design of the development of learning media was conducted using the modified models Borg and Gall and 4D Thiagarajan. (2) The application of VideoScribe-based learning media through activity as follows a) preparation, b) introduction, d) Evaluation, e) closing. (3) After applying VideoScribe-based learning media to improve students' ability on writing Descriptive Text in English subjects and conducted pretest and posttest, it can be concluded that there is an increase in students' ability in writing Descriptive Text before and after the use of learning media.
\end{abstract}

Keywords: Media; VideoScribe; Descriptive

\section{INTRODUCTION}

The general purpose of English language learning is so that students can obtain English language skills and can use these skills in communicating both orally and in writing. To obtain these skills, students must master language skills, one of which is writing skills. One of the basic competencies of writing in junior high school is composing and writing descriptive text. The author found that student learning outcomes in the material writing descriptive text have not been satisfactory. The limited learning media that can help students improve their writing skills and foster student interest is also an obstacle faced by teachers. Because of this, a variety of efforts are needed from the English teacher to improve students' ability in achieving the learning objectives of writing that have been predetermined. One effort that can be done is to develop learning media developed with VideoScribe that can help students improve English writing skills.

Writing is an act of expressing ideas and ideas through a series of words into a sentence and paragraph. Writing indirectly will help students learn because in the process of writing students use their eyes, hands, and ability to think together. Therefore, writing is one of the important skills to master. It is in line with the opinion of Raimes who revealed several reasons for the importance of mastering writing skills. According to Raimes (1983: 3) writing important is mastered because; (1) writing requires knowledge of Grammar, idioms, and vocabulary; (2) when students write, students also have an adventure in that 
language; (3) when writing students are very involved in the language they use.

But in reality, English language subjects are subjects that are considered difficult to learn, especially aspects of text writing skills. It is because English writing skills involve not only grammar and writing procedures but also the ability to express and develop ideas for writing. Heaton (in Alawiyah, 2017: 168) states that writing skills are more complex and difficult to teach and understand because they are not only about grammar and rhetoric but also in concepts and assessments. Elias, Akmaliah and Mahyuddin (in Cole and Feng, 2015: 5) state that the difficulty in writing English text is because students are worried about making mistakes in grammar and spelling.

Students of Mts At Taminiyah also experience the same thing. From the results of preobservations conducted by the author, students at MTs At-Taminiyah have not mastered English writing skills competently. Writing activity is not a preferred thing because students experience difficulties in writing essays well, especially in pouring ideas into writing. It can be seen from the frequent students asking when students are assigned to write such as the question of "how to, miss?"; "What is written?"; "What should be written?" Other problems that can be observed are the low mastery of vocabulary which results in inappropriate selection and use of words. The author found that there were $50 \%$ (15 out of 29 students) who made mistakes in writing English spelling, inappropriate word selection, and improper grammar. It results in low student achievement in writing assignments. To overcome these problems, various efforts are needed that can improve students' ability to write English texts. One of them is the use of learning media that can help and motivate students to write English texts.

Our learning media can be defined as various components of the learning environment that help students to learn (Gagne in Asyhar 2012: 7). One of the media that can be used is whiteboard animation learning media developed using VideoScribe. Based on previous research conducted by Dellyardianzah (2016: 8) shows that VideoScribe-based learning media can improve student learning outcomes. The same thing was also conveyed by Hakim, Shafira Aulia (2017: 6) who concluded that the use of VideoScribe media as one of the learning media could increase the activities and learning outcomes of students. Nurjanah et al. (2017: 230) emphasized that VideoScribe-based learning media is suitable for use as a learning medium.

Based on the author's experience, English learning activities at MTs At Taminiyah Sungai Kupah only use printed books as a medium of learning so that learning tends to be monotonous so that the results of student achievement in descriptive text writing material have not been satisfactory. With the right use and selection of media, it is expected that students' writing skills can increase.
Based on the description of the problems and previous research studies, the authors are interested in conducting development research with the title of VideoScribe-Based Learning Media Development to Improve the Writing Ability of Descriptive Text in English Subject.

\section{RESEARCH METHOD}

The purpose of this study, in general, is to develop learning media for video presentations to improve the ability to write descriptive text on English subjects. Therefore, the type of research that will be used in this research is research and development ( $R$ and $\mathrm{D}$ ). The research procedure carried out by the author in this research development took the steps of Borg \& Gall's development research combined with the design of the Thiagarajan 4D development model at the product development stage. However, this study did not use all the steps in the Borg \& Gall development research model and the Thiagarajan 4D development model design. Borg and Gall (1983: 792) explained that it was possible to research on a small scale by limiting the number of stages of the entire steps.

The steps of development research in this study consist of 5 main stages with the following explanation:

\section{Research and Collection of Information}

This stage is a preliminary study conducted to explore information needed in the development of VideoScribe-based learning media. Information is obtained through needs analysis and review of related documents and literature review. In the analysis phase of student needs, researchers collect data and information related to student problems, and needs include: a) curriculum analysis that applies, b) analysis of students' initial abilities, c) analysis of the availability of learning resources, d) analysis of learning tasks, e) analysis of learning models and methods, f) analysis of the use of learning media.

Planning

At this stage, the author identifies competencies that need to be mastered, formulates learning objectives achieved and determines the contents of the material be taught.

Design

In designing the initial product, researchers used the design stage in the Thiagarajan 4D development model with the following steps: (1) Formulating a constructing criterion-referenced test (2) Selecting media (media selection) (3) Selecting the format (format selection) (4) Initial design.

Product Development (Develop)

Product development consists of two steps, namely expert appraisal and product testing. Expert validation will involve three experts who will review the products produced, namely: 1) Material Expert; 2) Design Expert; and 3) Media Experts who are competent in their fields. After expert validation and revision of the initial design of the product, the next 
step is to conduct a trial followed by a revision based on the results of the trial. Product trials will be divided into three stages, namely: (1) Individual trial (One to one trial) (2) Small group trial (Small Group trial) (3) Field Try Out (Field test).

The final product

After testing the product and revising the final product of this study is a VideoScribe-based learning media.

Place and Research Subject

This research will be conducted in MTs At Taminiyah Sungai Kupah Village, Sungai Kakap District, Kubu Raya Regency. The research will be carried out in the 2017/2018 school year. Subjects in this study were divided into two, including: (1) Students of class VII MTs At Taminiyah Kubu Raya in the academic year 2017/2018 totaling 24 people. (2) English teachers who will be observed by two observers who are fellow researchers.

Data collection technique

The data obtained in this study consisted of qualitative data obtained from the review of material, design and media experts in the form of comments and suggestions from experts and quantitative data obtained from the results of questionnaires and test results in field trials. Data collection techniques used in this study are as follows: Non-Test Techniques and Test Techniques.

Data Collection Instrument

Instruments Collection of data used consists

of: (1) Questionnaire for student responses (2)

Questionnaire for validation by experts (3)

Observation Sheet (4) Performance Test.

Data analysis technique

Data analysis is carried out qualitatively and quantitatively. Qualitative analysis is carried out to process data obtained from expert reviews and observations. Quantitative analysis is used to process data obtained from expert validation questionnaires and questionnaire responses of students into the average value. For expert analysis validation questionnaires carried out are (1) Recording the value of expert validation results (2) Creating and analyzing validation results tables by experts (3) Finding the average of each criterion with the formula (in Khabibah: 2006):

Information :

$\mathrm{RKi}=$ Average criteria to $-\mathrm{i}$

$\mathrm{V} \mathrm{ji} \quad=$ The score of the $\mathrm{j}$-validator's assessment of the criteria for $-\mathrm{i}$

$\mathrm{n} \quad=$ Number of validators

The results obtained are written in the average column on the learning media validation analysis sheet.

(1) Finding an average aspect with the formula (Khabibah, 2006):

Information :

$$
R A i=\frac{\sum_{k=1}^{n} R K_{i j}}{n}
$$

RAi = Average aspect to $-\mathrm{i}$
RKij = Average for aspects of the $\mathrm{jth}$ criteria $-\mathrm{j}$

$\mathrm{n}=$ The number of criteria in the aspect of $-\mathrm{i}$

(2) Finding the average total validity of each aspect of the media with the formula (Khabibah, 2006):

With:

$$
R_{\text {media }}=\frac{\sum_{i=1}^{n} R A_{i}}{n}
$$

Va media = Average total media validity

$\mathrm{Ai}$

$\mathrm{n}$

$=$ Average aspect to $-\mathrm{i}$

$=$ The number of criteria in the aspect of - $i$

(3) Matching the total average with the modified media validity criteria (Khabibah, 2006):

Table I

Validation Criteria for Learning Media

\begin{tabular}{cc}
\hline Score & Validity Criteria \\
\hline $3<\mathrm{Va}_{\text {media }} \leq 4$ & Valid \\
$2<\mathrm{Va}_{\text {media }} \leq 3$ & Valid Enough \\
$1<\mathrm{Va}_{\text {media }} \leq 2$ & Not Valid \\
\hline
\end{tabular}

For response of questionnaire data analysis, students used percentages. The student response criteria are as follows:

Table II

Criteria for student response (in percentage\%)

\begin{tabular}{cc}
\hline Percentage & Category \\
\hline $\mathrm{Rs} \geq 85$ & Very Positive \\
$70 \leq \mathrm{Rs}<85$ & Positive \\
$50 \leq \mathrm{Rs}<70$ & Fair \\
$\mathrm{Rs}<50$ & Not Positive \\
\hline
\end{tabular}

(Khabibah, 2006 in Martha and Setianingsih 2014)

To process the data of the test results conducted in the pre-test and post-test used statistical analysis. The results of the pretest and posttest analysis were carried out: (1) Recap the students' pretest and posttest results in table (2) Summing up the pretest and posttest scores (3) Calculating the average pretest and posttest scores (4) After analyzing the results of the pretest and posttest, then the researcher conducted an analysis by t-test to determine the significance level of pretest and posttest acquisition, with the formula:

$$
\mathrm{t}=\frac{\overline{\mathrm{x}}_{1-\overline{\mathrm{x}}_{2}}}{\frac{\mathrm{SD}}{\sqrt{\mathrm{n}}}}
$$

Ket

$$
\begin{array}{ll}
\mathrm{X}_{-}^{-} 1 & \text { : Average X } 1 \\
\mathrm{X}_{-} 2 & \text { : Average X } 2 \\
\mathrm{SD} & \text { : Standard Deviation } \\
\mathrm{N} & \text { : Number of Samples }
\end{array}
$$

\section{RESULT AND DISCUSSION}

\section{A. Result}

\section{VideoScribe Based Learning Media Design}

The stages of designing VideoScribe-based learning media can be explained as follows:

1. Initial research and information gathering

The process carried out by researchers at the initial research stage and the collection of information 
includes analyzing student needs and studying literature. In the analysis phase of student needs, researchers collect data and information related to student problems and needs. The results obtained from this student needs analysis stage can be seen in the tables below:

Table III

Preliminary Observation Results (January 2018February 2018)

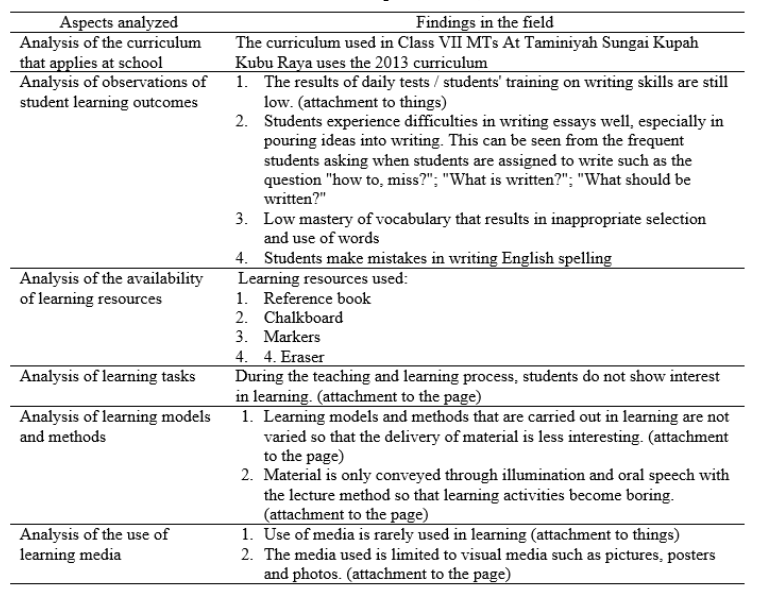

Based on the analysis, it can be concluded that there are still problems in learning English in Mts At Taminiyah Sungai Kupah Kab. Kubu Raya, especially in writing descriptive text, caused researchers to be interested in conducting development research. And as a solution to these problems, researchers developed a learning media based on VideoScribe to improve students' writing skills, especially the ability to write descriptive text

2. Planning phase

At this stage, the activities carried out are determining basic competencies, formulating learning objectives and determining learning materials. The initial design planned by researchers in developing learning media can be explained as follows:

\begin{tabular}{ll}
\hline \multicolumn{1}{c}{ Planning stage } & \multicolumn{1}{c}{ Information } \\
\hline $\begin{array}{l}\text { Determine Basic } \\
\text { Competencies }\end{array}$ & $\begin{array}{l}\text { Basic Competencies to be achieved in this study are KD 4.13: } \\
\text { Compile oral and written descriptive texts, very short and simple, about } \\
\text { people, animals and objects by taking into account the social function, text } \\
\text { structure, and linguistic elements correctly and in context. }\end{array}$ \\
\hline $\begin{array}{l}\text { Determine learning } \\
\text { objectives }\end{array}$ & $\begin{array}{l}\text { The objectives to be achieved from this learning are: } \\
\text { Students can write a simple descriptive text. }\end{array}$ \\
\hline $\begin{array}{l}\text { Determine learning } \\
\text { material }\end{array}$ & $\begin{array}{l}\text { The determination of learning material refers to Basic Competencies, } \\
\text { Indicators of Achievement of Competencies and learning objectives. Based } \\
\text { on KD, GPA and learning objectives that have been formulated, } \\
\text { researchers focus on the development of learning media for descriptive } \\
\text { writing text material. }\end{array}$ \\
\hline
\end{tabular}

\section{Design phase}

The next stage is the design stage. At the design stage, researchers carried out activities in the preparation of benchmark reference tests, selecting media, selecting formats and developing prototypes. The design stage is carried out as follows: (1) Preparing benchmark reference tests (2) Selecting (3) Selecting the format (5) Developing the initial product (prototype).

4. Development stage

The development or development stage is carried out by validating the product before the product is tested to students. Products will be validated by experts namely: learning material experts, learning media experts, and learning design experts.

Validation by material experts on VideoScribe-based learning media is carried out by one expert. The results of the validation results from the expert learning material are as follows:

\section{Table V}

Results of Validation of Expert Learning Materials

\begin{tabular}{llc}
\hline No & \multicolumn{1}{c}{ Aspects } & $\mathrm{Ai}$ \\
\hline 1 & $\begin{array}{l}\text { Clarity in the formulation of } \\
\text { objectives }\end{array}$ & 4 \\
\hline 2 & Material Compatibility & 4 \\
\hline 3 & Material Coverage & 4 \\
\hline 4 & Material Usefulness & 4 \\
\hline 5 & Presentation of Material & 4 \\
\hline 6 & Language Readability & 3.25 \\
\hline 7 & $\begin{array}{l}\text { Language Ability in delivering } \\
\text { material }\end{array}$ & 4 \\
\hline
\end{tabular}

Average overall $\mathrm{Va}$ material 3.89

Information :

$\mathrm{Ai}=$ Average validation value for each aspect Vamateri $=$ Average total validation

Validation analysis of material experts showed that VideoScribe-based learning media was said to be valid regarding the aspects of clarity in the formulation of objectives, material suitability, material coverage, material usefulness, material presentation, language readability and language ability in delivering material with an average value of 3.89 . Based on the validity criteria, regarding material, this VideoScribe-based learning media is declared feasible.

In addition to the assessment that is filled in the questionnaire sheet, there are also notes on 
suggestions and comments from the material experts as follows:

Table VI

Advice Notes and Material Expert Comments

Grammar should have no errors

Avoid using Informal Expression e.g I am gonna / wanna

Learning material is good, but it would be great if free error grammar. For example, singular and plural uses must be correct. If only one object / person, must use "a". For example: Parts of a bird, It is a bird. The name must be uppercase: Dovey.

4 In the discussion of yellow and red, the fonts should not be opposite. The yellow font in the red image is misleading.

An additional example is how an image is used as a source to write a descriptive text with clear instructions, such as size, quality, ability and example sentences.

Validation of VideoScribe-based learning media was carried out by two instructional media experts. The recapitulation results from the learning media experts can be seen in table 7 .

Table VII

Results of Learning Media Expert Validation

\begin{tabular}{lll} 
No & \multicolumn{1}{c}{ Aspects } & $\mathrm{Ai}$ \\
\hline 1 & Writing Display & 3.4 \\
\hline 2 & Image Display & 3.5 \\
\hline 3 & Layout & 3.4 \\
\hline 4 & Background Music & 3.5 \\
\hline 5 & Media Aspects & 3.3 \\
\hline & \\
\hline The overall average of $\mathrm{Va}_{\text {media }}$ & 3.42 \\
\hline
\end{tabular}

Information :

$\mathrm{Ai} \quad=$ Average validation value for each aspect Vamedia $=$ Average total validation

Vamedia value shows that the VideoScribe based learning media is valid with a validation value of 3.42. Experts also provide advice and responses to learning media. The suggestions and responses given include:

Table VIII

Media Advice Notes and Comments

\begin{tabular}{lll}
\hline No & \multicolumn{1}{c}{ Note Expert Advice and Comments } & \multicolumn{1}{c}{ Revision } \\
\hline I & $\begin{array}{l}\text { The media is good enough, it is recommended that } \\
\text { there be additional media for feedback to students. }\end{array}$ & Add additional media as feedback. \\
\hline 2 & Some slides / views are too fast, hard to listen to users & Slow down the slide show for a few seconds. \\
\hline 3 & $\begin{array}{l}\text { The final part of the media is not complete, something } \\
\text { must be done. }\end{array}$ & \\
\hline $4 \quad$ & $\begin{array}{l}\text { Add the vocabulary section to be filled in by students } \\
\text { as an exercise. }\end{array}$ & $\begin{array}{l}\text { Provides training in the vocabulary section to } \\
\text { be filled by students. }\end{array}$ \\
\hline
\end{tabular}

Validation by learning design experts on VideoScribe-based learning media was carried out by two experts. The recapitulation results from the learning design experts can be seen in the table below:

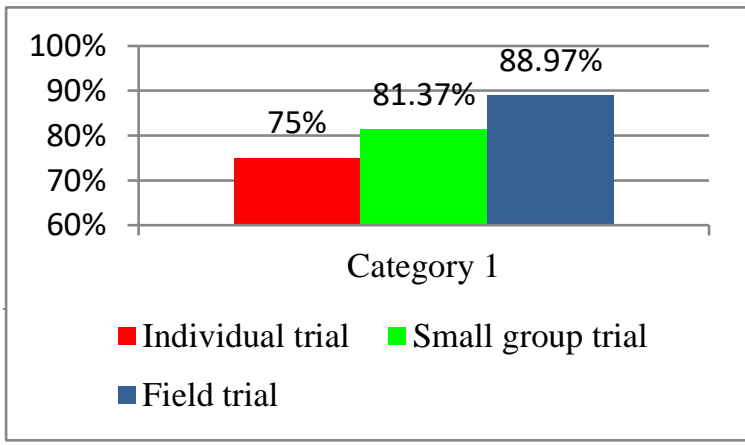

\begin{tabular}{clc}
\hline 3 & Coverage of learning materials & 4 \\
\hline 4 & Legibility & 4 \\
\hline 5 & Language skills in delivering material & 3.83 \\
\hline
\end{tabular}

Overall average $\mathrm{Va}_{\text {design }}$

Information :

$\mathrm{Ai}=$ Average validation value for each aspect

Design $=$ Average total validation

The overall value of the average validation regarding design aspects is 3.90 which means that the design of learning media has decent criteria. In addition to assessing the design aspects of the learning media, the design expert also provides the following suggestions and comments:

Table X

Advice Notes and Comments of Design Experts

\begin{tabular}{|c|c|c|}
\hline No & Expert Advice and Comments & Revision \\
\hline 1 & $\begin{array}{l}\text { It's good, the duration of time for long sentences is re- } \\
\text { considered. }\end{array}$ & $\begin{array}{l}\text { Slow the display duration in the slide } \\
\text { section too fast and the sentence is long. }\end{array}$ \\
\hline 2 & Don't display time too fast for every impression. & \\
\hline 3 & $\begin{array}{l}\text { Create a theoretical framework for animals: such as body } \\
\text { parts, colors, etc. }\end{array}$ & $\begin{array}{l}\text { Provide a theoretical framework for the } \\
\text { material to be discussed. }\end{array}$ \\
\hline 4 & Giving time to practice. & Provides practice as a form of feedback. \\
\hline
\end{tabular}

After validating the product, the researcher then revised the initial product. After being revised, the next stage of development is to conduct product trials on students by the designs that have been developed. This stage is carried out through three stages, namely individual trials, small group trials, and field tests.

Individual trials were conducted on 3 class VII students who were randomly selected. The results of the average value of student responses obtained by $75 \%$ with positive information. Small group trials were conducted on 9 class VII students who were randomly selected. Based on an analysis of student responses, the average value obtained was $81.37 \%$ with Positive criteria.

The next stage is for field trials. Field trials were carried out on 27 class VII students. The average total student response value is $88.97 \%$ with very positive criteria; this means the learning media has increased. The comparison of the results of student response questionnaires to interactive modules between individual trials, small group trials, and field tests can be seen in Figure 1. 
Fig. 1 Comparison of VideoScribe Based Learning Media Test Results

Based on graph 4.1 above it can be seen that there has been an increase in value from individual trials by $75 \%$, small group trials of $81.37 \%$ followed by field trials which have increased by $88.97 \%$ with very positive categories so that the learning media is getting closer to the perfect stage and can be used in the learning process.

5. Revision of the final product

The final product revision was carried out after the field trial was carried out. In the revision stage of the final product, the activities carried out are to improve the learning media developed. Improvements were made based on the results of the field trial analysis.

Application of VideoScribe Based Learning Media to Improve the Ability to Write Descriptive Text

The application of VideoScribe-based learning media is made in the process of learning English in the material of Descriptive text. There are several steps taken to implement the use of VideoScribe-based learning media in the class described in RPP (attached). The implementation activities of learning media include (1) Preparation (2) Introduction (3) Core Activities (4) Evaluation (5) Closing. At the core activities, learning media begin to be used. The application forms can be illustrated in the following activities, namely:

Improving the Ability to Write Students' Descriptive Text Using VideoScribe Based Learning Media

To find out the improvement of the ability to write descriptive text Research students will assess student learning outcomes before and after using VideoScribe-based learning media. The method used is an experimental study by giving pre-test and posttest before and after learning activities that use VideoScribe-based learning media. Student learning outcomes using VideoScribe-based learning media can be seen as follows:

\section{Pretest}

The pretest was given in the form of a practical test writing to 25 students of Class VII MTs At Taminiyah. Based on the results of the pretest implementation shows that the average value obtained is 55.63, which means that student learning outcomes are in a pretty good category.

\section{Posttest}

The posttest was given in the form of a practice test writing to 25 students of Class VII MTs At Taminiyah. Based on the results of the calculation of student learning outcomes on the implementation of posttest shows that the average value obtained is
67.88 , which means that student learning outcomes are in good category.

The comparison of learning outcomes obtained by students at the pretest and posttest can be seen in the following graph:

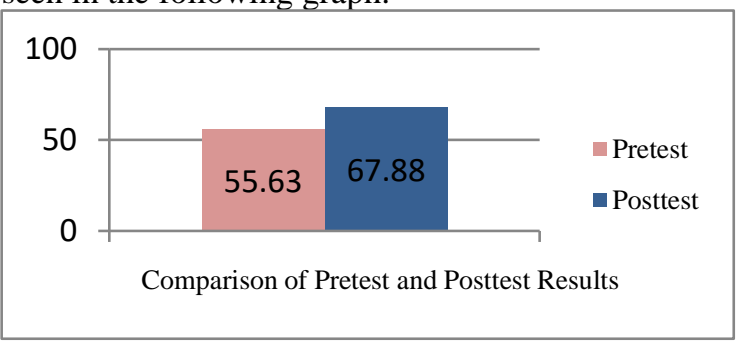

Fig. 2 Comparison of Pretest and Posttest Results

T-test

The T-test is to test the difference between two paired samples. The sample referred to here is the result of the students' pretest and posttest. The results obtained from the calculation results are the value of $t$ count $>t$ table $(11.76>1.717)$ at $\alpha=5 \%$ with $\mathrm{df}=\mathrm{n}-1$. Then the conclusion is Ho is rejected, and Ha is accepted. It means that there are differences in learning outcomes between before using learning media and after using learning media.

\section{B. Discussion \\ VideoScribe Based Learning Media Design}

To develop a product, the initial stage that must be passed is to design the initial product or design that will be developed. The initial product design is a preliminary activity carried out to obtain a reference in developing a product. A good preliminary design will maximize product development so that a product that can be used as a support for learning can be obtained.

According to Gustasfon and Branch (in Pribadi, 2010: 87) there are three design models that can be used for the development of learning namely (1) a class-oriented model (Classroom oriented model); (2) Product-oriented model (Product oriented model); (3) System-oriented models (System oriented models). In this development study, the authors developed a product in the form of VideoScribe-based learning media, so that the learning design model used was a product-oriented 4D-Thiagarajan development model design (Product oriented model) combined with Borg \& Gall's research model design.

With the findings of the research results that have been described, the results of the study of the design of VideoScribe-based learning media begin with conducting initial research and gathering information. At this stage, researchers conduct school curriculum analysis, analysis of student learning outcomes, analysis of availability of learning resources, analysis of learning assignments, analysis of learning models and methods and analysis of the use of learning media. After collecting initial information, the next step is to do planning by determining basic 
competencies, formulating learning objectives and determining learning material.

After planning, the researcher then began designing the product developed. The drafting activity starts with compiling benchmark reference tests, selecting media, selecting formats and developing prototypes. The product prototype that has been designed is then developed through two stages: the validity test stage and the empirical test stage. The validity test phase was carried out by three experts, namely material experts, learning media experts, and learning design experts. Expert learning materials consist of 1 person, instructional media experts consisting of 2 people, and learning design experts consisting of 2 people. After passing the validity test by experts, researchers made improvements based on suggestions and input from the expert.

The results of product revisions were then retested through empirical tests conducted in 3 stages of testing, namely individual trials, small group trials, and field trials. After testing the product has been in the final stages of development.

Application of VideoScribe Based Learning Media to Improve the Ability to Write Descriptive Text

In implementing VideoScribe-based learning media, researchers have designed activities during learning. It is done so that the learning process is by the learning objectives that will be achieved and so that the learning media that has been developed can truly be applied to helping students learn. The learning activities that have been designed consist of several steps.

The first step before implementing the VideoScribe-based learning media, researchers first conduct a series of preparations, namely by preparing supporting tools to mark learning media such as projectors and laptops, preparing questionnaires and observations for observers, as well as other supporting needs such as markers and erasers. The next step is the core activity. At the core activities, learning media begin to be used. The form of application can be illustrated in the following activities. First, the teacher displays VideoScribe-based learning media through the projector screen and asks students to focus on the projector screen, and students watch a presentation video about the descriptive text material being displayed. The teacher then pauses on the video section which explains descriptive text material and gives students the opportunity to ask questions. After the question and answer session ends the students are conditioned again to continue watching the presentation video. Next, the students are invited to do the exercises. At this stage, the video will pause in several sections that contain the training section. Students are then guided to work on the exercises provided.

The last activity is a closing. At this stage, the teacher and students conclude the learning material that has been broadcast through VideoScribe-based learning media. The teacher then provides an evaluation followed by reflection, provides information about the follow-up to learning, and ends the lesson with greetings.

Based on the learning steps that have been made and done by researchers in learning it can be seen that the approach used is a behavioristic approach. It is in line with the principles of behavioristic theory (Hartley \& Davies in Seokamto \& Winataputra, 1997: 19), among others: (1) The learning process can occur well if students participate actively in the learning process. (2) Learning material is formed in small units and arranged in a logical order so that it is easy to learn. (3) Each response needs to be given immediate feedback. (4) every time a correct response is given it needs to be accompanied by reinforcement.

In the learning process that has been carried out, the teacher is only as a facilitator and students are more active and more enthusiastic in carrying out learning using learning media. It is supported by observations by two observers who observed during the learning process in class. Also, the subject matter presented through learning media is divided into small units and arranged in a logical sequence that directs students to learn to write descriptive texts starting from sentence identification to the description sentence. The application of this learning media is also accompanied by training as feedback for students.

Improving the Ability to Write Students' Descriptive Text Using VideoScribe Based Learning Media

The purpose of this study is to develop VideoScribe-based learning media to improve the ability to write descriptive text. The use of appropriate learning media can help improve students' learning abilities. Meyer (in Asyhar, 2012: 28) suggests that someone will learn better when learning from text and image media rather than text media only. VideoScribe based learning media is a medium that contains text and images so that it can help students learn better. Based on previous research conducted by Dellyardianzah (2016: 8) shows that VideoScribebased learning media can improve student learning outcomes. It is also evident from the results of research researchers which showed that there was an increase in the ability to write descriptive text after using VideoScribe-based learning media. Researchers used a tool in the form of research instruments in the form of pretest and posttest questions to determine the improvement of students' descriptive text skills.

The pretest is done before the learning process using VideoScribe-based learning media with the aim of knowing the students' initial abilities in mastering the subject matter. From the results of the pretest, the researcher obtained an average score of 55.63, which means that the learning outcomes of students were in the category of good enough, then after the implementation of learning using learning media based on VideoScribe researchers conducted posttest on students with the aim of knowing learning outcomes after using VideoScribe-based learning 
media. From the results of the posttest, the researcher obtained an average score of students at 67.88, meaning that the student's score has increased and is in a good category.

Based on the results of the pretest and posttest obtained, the researcher then conducted a paired sample t-test. The results obtained based on the calculations performed are the value of $\mathrm{t}$ count $>\mathrm{t}$ table (11.76> 1.717) $\alpha=5 \%$ with $\mathrm{df}=\mathrm{n}-1$. Then the conclusion is Ho is rejected, and $\mathrm{Ha}$ is accepted. It means that there are differences in learning outcomes between before using learning media and after using learning media.

The results obtained indicate that the desired learning objectives experience achievement, namely students experience increased ability to write descriptive text.

\section{CONCLUSIONS AND SUGGESTIONS}

\section{A. Conclusions}

Based on the results of the research that has been done, it can be concluded that the design of VideoScribe-based learning media development to improve the ability to write Descriptive Text in English subjects is done using the Borg and Gall and 4D Thiagarajan modification models with the stages: (1) the initial research stage and information gathering , (2) the planning stage, (3) the design stage, (4) the development stage, (5) revision and (6) the final product. The design results are then applied in learning through the preparation, introduction, core activities, evaluation, and closing stages. After applying VideoScribe-based learning media to improve the ability to write Descriptive Text in English subjects and do the pretest and posttest, it was found that there was an increase in students' ability to write Descriptive Text before and after the use of learning media. B. Suggestions

Based on the results of the research that has been done, researchers can see that the learning media developed has the feasibility of improving students' abilities. Therefore, the researchers propose the following suggestions: 1) Researchers suggest that researchers who will conduct development research can design and develop learning media that are more varied and better to use a model design that is appropriate to the development orientation and research needs. 2) The application of this learning media uses a behavioristic approach where the focus is in the form of student learning outcomes. Researchers recommend that teachers be able to use learning approaches and methods that are better and by the needs of students. 3) From the results of the study, it was found that VideoScribe-based learning media can improve students' writing skills. Teachers are advised to be able to use or develop similar learning media or other media that can help students in learning and help students improve their learning outcomes. To the students, the researchers suggested that they could use the existing learning media to help and facilitate the learning activities carried out.

\section{REFERENCES}

Alawiyah, Luluk. (2017). Pengembangan Materi Menulis Descriptive Text melalui Media Flash: Studi Kasus di SMP Islam Roudlotus Saidiyah Gunungpati Semarang. Jurnal PPKM. Vol II. ISSN 2354-869X: 167-174.

Asyhar, Rayandar. (2012). Kreatif Mengembangkan Media Pembelajaran. Jakarta: Referensi Jakarta

Borg, W.R \& Gall, M.D. (1983). Educational Research: An Introduction. New York: Longman

Cohen, Louis. Manion, Lawrence \& Morrison, Keith. (2007). Research Methods in Education: Sixth Edition.New York: Routledge

Cole, Jenny \& Feng, Jay. (2015). Effective Strategies for Improving Writing Skills of Elementary English Language Learners. Chinese American Educational Research and Development Association Annual Conference. Chicago

Dellyardianzah. (2017). Penggunaan Media Pembelajaran Berbasis VideoScribe untuk Meningkatkan Hasil Belajar Siswa pada Mata Pelajaran Ekonomi. Jurnal. Universitas Tanjung Pura Vol 6. No. 10 (diakses pada hari Jum'at, 16 februari 2018 dari https://www.neliti.com)

Hakim, Shafira Aulia. (2017). Pengaruh Media VideoScribe terhadap Hasil Belajar Siswa pada Materi Interaksi Makhluk Hidup dengan Lingkungan di Kelas VII SMPN Simpang Tiga Kab. Aceh Besar. Skripsi. Banda Aceh: UIN Ar -Raniry

Heaton, J.B. (1989). Writing English Language Test. New York: Longman Group UK

Khabibah, Siti. (2006). Pengembangan Model Pembelajaran Matematika dengan Soal Terbuka untuk meningkatkan kreativitas Siswa Sekolah Dasar. Disertasi, Tidak dipublikasikan. Surabaya. Unesa.

Martha, Inneke Rheyza \& Setianingsih, Rini. (2014). Penerapan Model Pembelajaran Kooperatif Ditinjau dari Tipe Kecerdasan Musikal, Interpersonal, dan Logika Matematika pada Materi Persegi dan Persegi Panjang. Jurnal Ilmiah Pendidikan Matematika. Volume 3 No 1 .

Nurjanah, Fitri. dkk. (2017). Pengembangan Media Animasi Menggunakan Software Videoscribe pada Materi Minyak Bumi Kelas X MIA di MAN Darussalam. Jurnal Ilmiah Mahasiswa Pendidikan Kimia. Vol. 2 No. 4.

Raimes, Ann. (1983). Techniques in Teaching Writing. Oxford: Oxford University Press. 